\title{
Article \\ Structural, Optical, and Antibacterial Efficacy of Pure and Zinc-Doped Copper Oxide Against Pathogenic Bacteria
}

\author{
Awais Khalid ${ }^{1}\left(\mathbb{D}\right.$, Pervaiz Ahmad ${ }^{2, *} \mathbb{1}$, Abdulrahman I. Alharthi ${ }^{3}$, Saleh Muhammad ${ }^{1}$, \\ Mayeen Uddin Khandaker ${ }^{4}$, Mubasher Rehman ${ }^{5}$, Mohammad Rashed Iqbal Faruque ${ }^{6}$, Israf Ud Din ${ }^{3}$, \\ Mshari A. Alotaibi ${ }^{3}$, Khalid Alzimami ${ }^{7}$ and David A. Bradley ${ }^{4,8}$
}

1 Department of Physics, Hazara University, Mansehra 21300, Pakistan; awais.phy@hu.edu.pk (A.K.); saleh@hu.edu.pk (S.M.)

2 Department of Physics, University of Azad Jammu and Kashmir, Muzaffarabad 13100, Pakistan

3 Department of Chemistry, College of Science and Humanities, Prince Sattam Bin Abdulaziz University, P.O. Box 173, Al-Kharj 11942, Saudi Arabia; a.alharthi@psau.edu.sa (A.I.A.); i.din@psau.edu.sa (I.U.D.); alosaimi@psau.edu.sa (M.A.A.)

4 Center for Applied Physics and Radiation Technologies, School of Engineering and Technology, Sunway University, Bandar Sunway 47500, Selangor, Malaysia; mayeenk@sunway.edu.my (M.U.K.); d.a.bradley@surrey.ac.uk (D.A.B.)

5 Department of Microbiology, Hazara University, Mansehra 21300, Pakistan; mubasherrehman08@gmail.com

6 Space Science Centre, Universiti Kebangsaan Malaysia (UKM), Bangi 43600, Selangor, Malaysia; rashed@ukm.edu.my

7 Department of Radiological Sciences, College of Applied Medical Sciences, King Saud University, P.O. Box 10219, Riyadh 11433, Saudi Arabia; kalzimami@ksu.edu.sa

8 Department of Physics, University of Surrey, Guildford GU2 7XH, UK

check for

updates

Citation: Khalid, A.; Ahmad, P.; Alharthi, A.I.; Muhammad, S.; Khandaker, M.U.; Rehman, M.; Faruque, M.R.I.; Din, I.U.; Alotaibi, M.A.; Alzimami, K.; et al. Structural, Optical, and Antibacterial Efficacy of Pure and Zinc-Doped Copper Oxide Against Pathogenic Bacteria.

Nanomaterials 2021, 11, 451. https:// doi.org/10.3390/nano11020451

Received: 27 January 2021

Accepted: 8 February 2021

Published: 10 February 2021

Publisher's Note: MDPI stays neutral with regard to jurisdictional claims in published maps and institutional affiliations.

Copyright: (c) 2021 by the authors. Licensee MDPI, Basel, Switzerland. This article is an open access article distributed under the terms and conditions of the Creative Commons Attribution (CC BY) license (https:// creativecommons.org/licenses/by/ $4.0 /)$.

* Correspondence: pervaiz_pas@yahoo.com; Tel.: +92-345-9493879

\begin{abstract}
Copper oxide and Zinc ( $\mathrm{Zn}$ )-doped Copper oxide nanostructures (CuO-NSs) are successfully synthesized by using a hydrothermal technique. The as-obtained pure and $\mathrm{Zn}$-doped CuO-NSs were tested to study the effect of doping in $\mathrm{CuO}$ on structural, optical, and antibacterial properties. The band gap of the nanostructures is calculated by using the Tauc plot. Our results have shown that the band gap of $\mathrm{CuO}$ reduces with the addition of Zinc. Optimization of processing conditions and concentration of precursors leads to the formation of pine needles and sea urchin-like nanostructures. The antibacterial properties of obtained $\mathrm{Zn}$-doped CuO-NSs are observed against Gram-negative (Pseudomonas aeruginosa, Klebsiella pneumonia, Escherichia coli) and Gram-positive (Staphylococcus aureus) bacteria via the agar well diffusion method. Zn doped s are found to have more effective bacterial resistance than pure $\mathrm{CuO}$. The improved antibacterial activity is attributed to the reactive oxygen species (ROS) generation.
\end{abstract}

Keywords: copper oxide; zinc-doping; hydrothermal; antibacterial activity

\section{Introduction}

The manipulation of size, composition, and morphology of technologically significant materials ranging from nanometer to micrometer has been a major challenge for scientists over the past several decades [1]. Metal oxide nanostructures possess special physical and chemical properties due to their finite size and large surface area. Metal oxides have attracted great interest from scientists due to their multi-discipline applications [2-4]. Copper oxide $(\mathrm{Cu})$ is among the most significant p-type semiconductors, having $\mathrm{Cu}$ atoms on Face centered cubic (FCC) and oxygen (O) atoms at the center with a band gap of $1.2 \mathrm{eV}-1.9 \mathrm{eV}[5,6]$. CuO-based nanomaterials are extensively studied and used in various applications due to their unique properties, i.e., high physical and chemical stability, nontoxicity, narrow optical band gap, infrared photodetection, and ferromagnetic behavior (because of its opposite surface spin) [7-10]. Moreover, in certain semiconductors and 
oxide-based materials, optical, magnetic, and electronic properties are often observed [7]. The three most important oxidation states of copper is $\mathrm{Cu}^{+}, \mathrm{Cu}^{2+}$, and $\mathrm{Cu}^{3+}$, causing the possibility to dope electrons and holes [8]. These properties make $\mathrm{CuO}$ an ideal contender for a variety of applications, including gas sensors, solar cell, supercapacitors, lithium-ion electrode resources, superconductors, magnetic storage media, and catalysis. So far, various copper oxide nanostructures (CuO-NSs) have been reported, including one dimensional, two dimensional, spherical, and hierarchical structures [11-14]. $\mathrm{Cu}$ is a well-known antibacterial agent due to its high efficacy against bacteria [15,16]. CuO nanoparticles kill bacteria by the release of $\mathrm{Cu}^{2+}$ ions [17]. $\mathrm{ZnO}$ is also known for its significant inhibition of bacterial growth in a wide range of bacteria, caused by the production of reactive oxygen species (ROS) formed in water $[18,19]$. During interaction with water, $\mathrm{ZnO}$ reduces oxygen to water and produces three intermediate ROS; hydroxyl radical, hydrogen peroxide, and superoxide $[20,21]$. These types of species play a key role in killing gram-positive and gram-negative bacteria. The ROS generation in a nanomaterial structure by zinc oxides depends on the existence of defect sites [22].

$\mathrm{Zn}^{2+}$ dopant has been documented to be the most successful in producing defects in $\mathrm{CuO}$ nanostructures that might have the potential for biological applications [23]. Due to $\mathrm{Cu}^{2+}(0.072 \mathrm{~nm})$ and comparable ionic states being almost the same ionic radius of $\mathrm{Zn}$ $(0.074 \mathrm{~nm}), \mathrm{Zn}^{2+}$ is promising in various fields. $\mathrm{Zn}$-doped $\mathrm{CuO}$ oxide has been reported as an excellent candidate for anti-bacterial resistance. $\mathrm{Zn}$ - $\mathrm{CuO}$ nanoparticles with antibacterial drugs could be deposited on the cotton substrate to attain an anti-bacterial cotton bandage [24]. The combined antibacterial properties of $\mathrm{CuO}$ and $\mathrm{ZnO}$ can be investigated by doping $\mathrm{Cu}$ into the matrix of $\mathrm{ZnO}$ or doping $\mathrm{Zn}$ into the matrix of $\mathrm{CuO}$. The production of strong resistance pathways to such hybrid metal particles becomes a challenge for bacteria [25].

Various preparation methods for nanostructures are described in the literature, such as sol-gel combustion, co-precipitation, chemical vapor deposition, laser ablation, hydrothermal treatment, ball mill, and microwave-assisted synthesis, etc. [26,27]. An economical and environmentally-friendly method was developed for the synthesis and functionalization of copper oxide $(\mathrm{CuO})$ nanosheets by chemical grafting of 3-(chloropropyl) triethoxysilane (CIPTES), diethanolamine (DEA), and $p$-amino thiophenol (ATP), with potential uses in catalysis and biomedical applications [28]. Silver-doped $\mathrm{CuO}$ was found to have promising prospects for potential applications as an inexpensive catalyst in wastewater treatment and antibacterial agent in cosmetics [29]. The antibacterial activity of Mg-doped $\mathrm{ZnO}$ nanoparticles (NPs), synthesized by the green chemistry route using malabathricum leaf extract [30], and size-dependent activity of ZnO-NPs, synthesized by various concentrations of Mar Ivanios leaf extract, were tested against different clinical strains. It was observed that as the concentration of NPs increases, the antibacterial activity also increases [31]. The $\mathrm{ZnO}-\mathrm{CuO}$ composites synthesized using colotropis gigantea leaf extract by a combustion method shows good antibacterial activity [32]. The synthesis of a Zinc (Zn)-doped Copper oxide nanostructure ( $\mathrm{Zn}$-doped $\mathrm{CuO}-\mathrm{NS}$ ) and its chemical and physical properties, including its crystal structure and magnetization, has been explored as a function of temperature [33]. Similarly, it was found that doping of magnesium in CuO-NSs possesses anti-cancer and antimicrobial activity for various microbial strains [34]. There have also been reports on the antimicrobial activity of $\mathrm{Zn}$-doped $\mathrm{CuO}$-coated fabrics experienced against $E$. coli, S. aureus, and multidrug-resistant bacteria [24].

Previously, many researchers have carried out doping with transition metal in $\mathrm{CuO}$ using various methods, but only a few of these works are about $\mathrm{Zn}$-doped CuO-NSs. The structural, morphological, optical, and antibacterial properties of nanomaterials depend mainly on the impurities and defects existing in a host matrix. The modification in the properties of $\mathrm{CuO}$ is observed by introducing dopants into the lattice. Thus, this study examined the effect of pure and $\mathrm{Zn}$-doped CuO-NSs on gram-positive bacterium (S. aureus) and gram-negative bacterium (P. aeruginosa, K. pneumonia, E. coli). We observed enhanced killing of gram-negative and gram-positive bacterial strains by the Zn-doped CuO-NS. 


\section{Materials and Methods}

\subsection{Materials}

Zinc chloride $\left(\mathrm{ZnCl}_{2}\right)$, Copper II chloride dihydrate $\left(\mathrm{CuCl}_{2} \cdot 2 \mathrm{H}_{2} \mathrm{O}\right)$, and Potassium hydroxide $(\mathrm{KOH})$ were purchased from Sigma Aldrich, St. Louis, MI, USA. Structural analysis of $\mathrm{Zn}$-doped $\mathrm{CuO}$ samples was carried out by using an X-ray diffractometer (Ultima IV Rigaku International Corp., Tokyo, Japan), scanned and recorded at 20-70 at CuK radiation $(\lambda=1.54056 \AA)$. The surface morphology of pure and $\mathrm{Zn}$-doped CuONSs was examined with a FE-SEM (QUANTA 250 FEI). X-ray photoelectron spectroscopy (XPS; Thermo specific model K-ALPHA) was used to investigate the surface elemental composition. To perform the antibacterial activity, four different bacterial strains were used, namely, Pseudomonas aeruginosa $\left(\right.$ ATCC $\left.{ }^{\circledR} 10145\right)$, Klebsiella pneumonia $\left(\right.$ ATCC ${ }^{\circledR}$ BAA1144), and Escherichia coli (ATCC $\left.{ }^{\circledR} 33876\right)$ as gram-negative and while Staphylococcus aureus $\left(\right.$ ATCC $\left.^{\circledR} 11632\right)$ as gram-positive bacteria. Nutrient agar (Oxoid ${ }^{\circledR}$ CM0003) was purchased from Sigma-Aldrich.

\subsection{Synthesis of $\mathrm{Zn}$-Doped $\mathrm{CuO}-\mathrm{NSS}$}

$\mathrm{CuCl}_{2} \cdot 2 \mathrm{H}_{2} \mathrm{O}, \mathrm{ZnCl}_{2}$, and $\mathrm{KOH}$ were taken as precursors. At first, a mixture of $3.4 \mathrm{~g}$ of $\mathrm{CuCl}_{2} \cdot 2 \mathrm{H}_{2} \mathrm{O}$ was dissolved into $40 \mathrm{~mL}$ of deionized water. For the doped sample, $0.85 \mathrm{~g}$ of $\mathrm{ZnCl}_{2}$ was added along with $\mathrm{CuCl}_{2} \cdot 2 \mathrm{H}_{2} \mathrm{O}$. Afterward, $2.7 \mathrm{~g}$ of $\mathrm{KOH}$ was separately dissolved in $40 \mathrm{~mL}$ of deionized water and added dropwise to the already made homogeneous solution of $\mathrm{CuCl}_{2} \cdot 2 \mathrm{H}_{2} \mathrm{O}$. At room temperature, the solution was stirred for $30 \mathrm{~min}$. The final solution was transferred to a (Teflon-lined) autoclave then placed in the oven at $180^{\circ} \mathrm{C}$ for $18 \mathrm{~h}$. As a result, a dark brown and aquamarine precipitate was obtained for pure and $\mathrm{Zn}$-doped samples. The as-obtained dark brown and aquamarine precipitate was then washed many times with distilled water and ethanol. Finally, the precipitate was kept for drying in the oven at $120^{\circ} \mathrm{C}$ for $2 \mathrm{~h}$.

\subsection{Screening of Antibacterial Activity}

For screening of antibacterial efficacy of $\mathrm{CuO}$ and $\mathrm{Zn}$-doped $\mathrm{CuO}-\mathrm{NSs}$, all bacterial strains were sub-cultured from their pure cultures in Luria broth media (containing 17\% glycerol) and subjected to overnight incubation. For the antibacterial assay, the fresh cultures were used by transferring the stock suspensions on nutrient agar (Oxoid ${ }^{\circledR} \mathrm{CM} 0003$ ) and incubated at $37^{\circ} \mathrm{C}$ for $24 \mathrm{~h}$. Bacterial culture turbidity was settled to the $0.5 \mathrm{McF}$ arland (freshly prepared) standard [35], which is equal to $1.5 \times 10^{8} \mathrm{CFU} / \mathrm{mL}$ bacteria. Every species was spread on a nutrient agar Petri plate with the help of a sterile glass spreader. By using a sterile polystyrene tip, $4 \mathrm{~mm}$ wells were rendered. Pure and $\mathrm{Zn}$-doped CuO-NSs with various concentrations, including 3,5 , and $10 \mathrm{mg} / \mathrm{mL}$, were prepared in $20 \%$ dimethyl sulfoxide (DMSO). In each well, $40 \mu \mathrm{L}$ concentration was added, which was taken from the prepared solution. All the plates were placed in an incubator overnight at $37^{\circ} \mathrm{C}$ for incubation. By using a caliper, the inhibition zone was measured in millimeters around each well. Ciprofloxacin, as a standard reference antibiotic, was used at a $40 \mu \mathrm{g} / \mathrm{mL}$ concentration. The mean value was reported for each experiment, carried out in triplicate $(\mathrm{N}=3)$.

\section{Results and Discussion}

The characterization of hydrothermally prepared $\mathrm{CuO}$ and $\mathrm{Zn}$-doped $\mathrm{CuO}-\mathrm{NSs}$ was performed by using a field emission scanning electron microscope (FE-SEM) to observe its apparent shape. Figure 1a,b shows the FE-SEM micrographs of the synthesized pure $\mathrm{CuO}$ in low and high magnifications. Similarly, Figure 1c,d shows the FE-SEM micrographs of $\mathrm{Zn}$-doped CuO-NSs in lower and high magnifications. The morphologies of both pure and $\mathrm{Zn}$-doped $\mathrm{CuO}-\mathrm{NSs}$ were very interesting. The structure of pure $\mathrm{CuO}$ seemed to be feather-like and changed to a pine needle-, sea-urchin- [36], or block-like structure with Zinc doping. The change in the morphology might be due to $\mathrm{Cu}^{2+}(0.73 \AA)$ replacement with $\mathrm{Zn}^{2+}(0.74 \AA)$ in the $\mathrm{CuO}$ lattice. Feather-like structures in pure $\mathrm{CuO}$ had a thickness 
in the range of 50-100 nm. The pine needle-like structures in the $\mathrm{Zn}$-doped sample varied in the range of 80-100 $\mathrm{nm}$, whereas the block-like structures were found to vary in size from $80-200 \mathrm{~nm}$. The observation of the FE-SEM results shows the variation in size and morphology of the structures with doping of $\mathrm{Zn}$. The size and shape of CuO-NSs were found to depend on the $\mathrm{Zn}$ additive. These findings were found to be in close agreement with the previous findings [37].

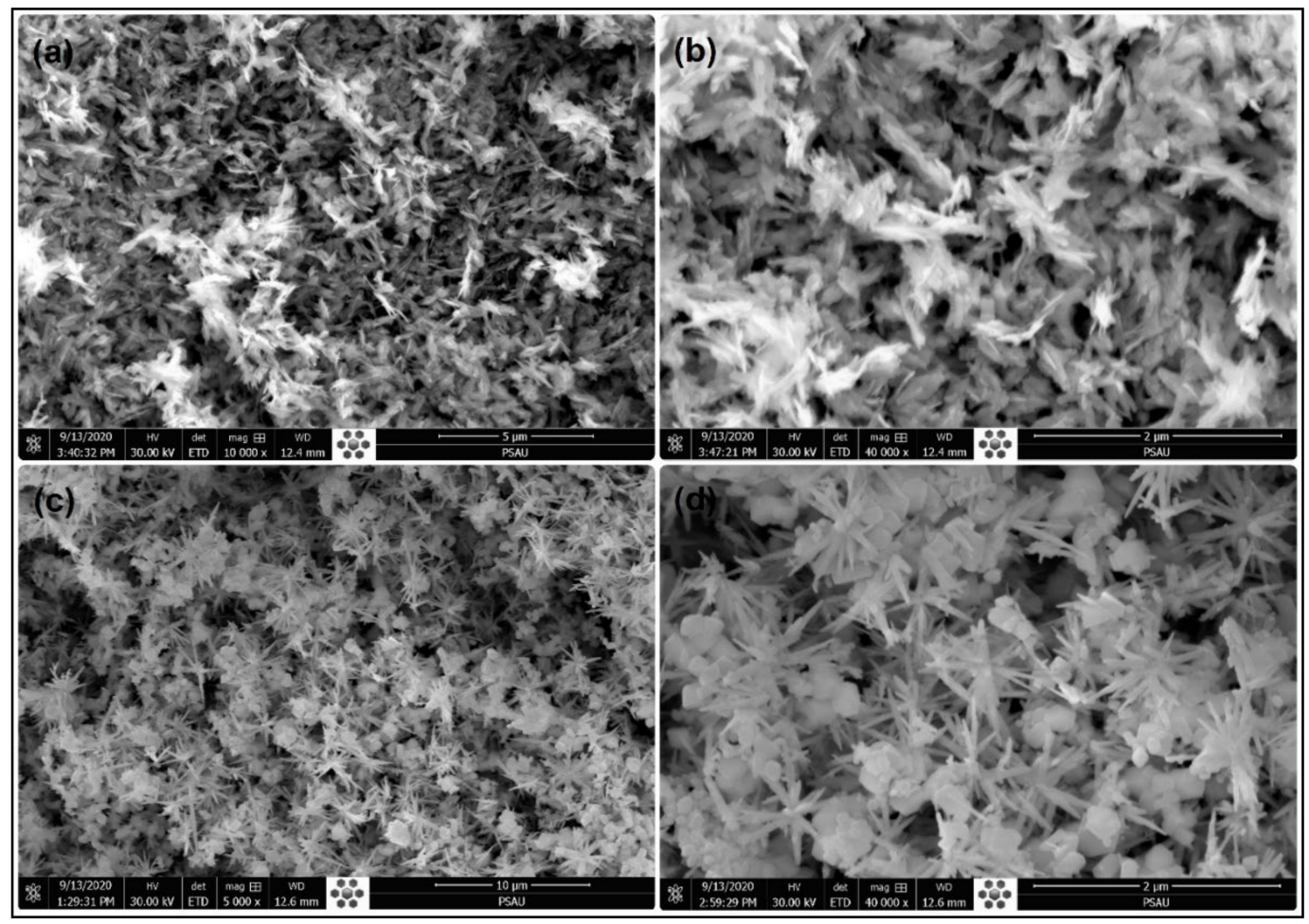

Figure 1. FE-SEM micrographs of the $(\mathbf{a}, \mathbf{b})$ pure copper oxide and (c,d) shows the micrographs of Zinc (Zn)-doped Copper oxide (Zn-doped $\mathrm{CuO})$.

The x-ray diffraction (XRD) spectrum of the synthesized $\mathrm{CuO}$ and $\mathrm{Zn}$-doped CuO-NSs were displayed in Figure 2. The compositions, phase, and crystallite size of the material were determined by intensities and peak positions of the observed peaks. The peaks in the displayed XRD pattern appeared at $2 \theta$ different values. According to "Inorganic crystal structure database (ICSD) reference No. 01-080-1268", the peaks found at $29.42^{\circ}, 32.53^{\circ}$, $35.5^{\circ}, 38.7^{\circ}, 48.6^{\circ}, 53.51^{\circ}, 58.29^{\circ}, 61.51^{\circ}, 66.17^{\circ}$, and $68.07^{\circ}$ corresponded to (210), (110), (002), (111), (-202), (020), (202), (-113), (-311), and (220) planes in the monoclinic structure of $\mathrm{CuO}$ [38-40]. The sharpness of the peaks indicated that pure $\mathrm{CuO}$ was highly crystalline. In $\mathrm{Zn}$-doped $\mathrm{CuO}$, the XRD pattern peaks appeared at a $2 \theta$ value of $26.20^{\circ}, 30.97^{\circ}, 32.42^{\circ}$, $35.64^{\circ}, 38.97^{\circ}, 39.86^{\circ}, 40.97^{\circ}, 47.74^{\circ}, 48.59^{\circ}, 53.6^{\circ}, 56.41^{\circ}, 57.52^{\circ}, 58.41^{\circ}, 61.74^{\circ}, 63.68^{\circ}$, $66.17^{\circ}, 67.85^{\circ}, 68.73^{\circ}$, and $69.40^{\circ}$, respectively. These peaks, according to "ICSD reference No. 001-1136", corresponded to (003), (100), (110), (002), (111), (200), (012), (102), (-202), (020), (021), (110), (202), (-113), (-311), (112), (220), and (004) planes [41], which shows that the $\mathrm{Zn}^{2+}$ ions were incorporated effectively to the site of $\mathrm{CuO}$ lattice without interrupting the $\mathrm{CuO}$ crystal structure. Due to the resemblance in the $\mathrm{Zn}^{2+}(0.74 \AA)$ and $\mathrm{Cu}^{2+}(0.73 \AA)$ radius, $\mathrm{Cu}^{2+}$ ions can be well substituted by $\mathrm{Zn}^{2+}$ ions in the lattice structure. 


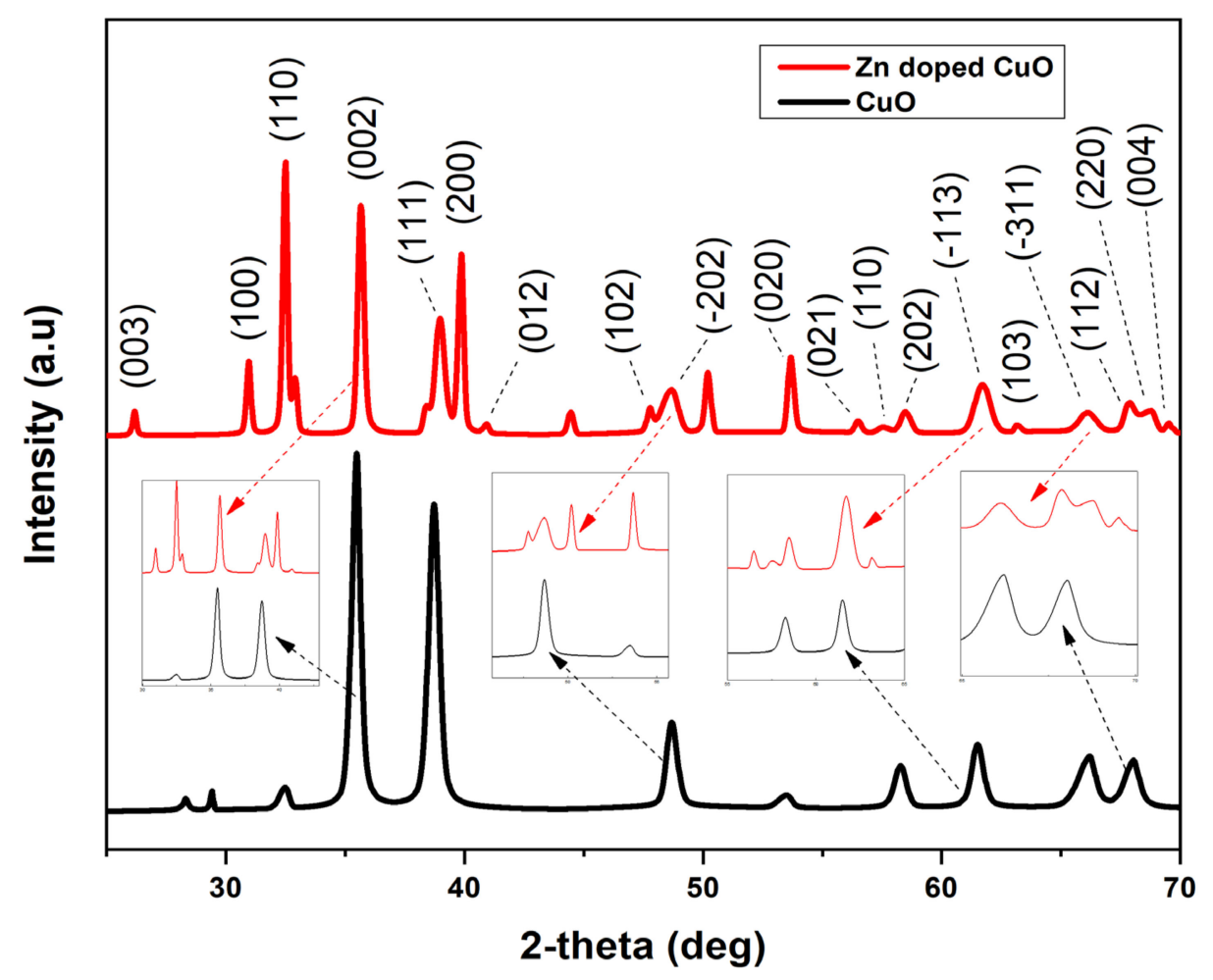

Figure 2. XRD pattern of $\mathrm{Zn}$-doped $\mathrm{CuO}$ nanoparticles showing peaks for different content in the sample.

The particle size and strain were investigated by using the Williamson-Hall (W-H) method, as displayed in Figure 3, for pure and Zn-doped CuO-NSs. The W-H method varies with $\tan \theta$ instead of $1 / \cos \theta$, as followed in the Debye Scherrer equation. This essential variation allows one to separate the broadening of reflection, along with both microstructural reasons (micro-strain and small crystallite size) that occur together. The microstructural parameters were calculated, including the size of crystallite D and micro-strain $(\varepsilon)$ for the prepared samples. It was found that the average size of $\mathrm{CuO}$ crystallites increased and $\varepsilon$ decreased with increasing Zn concentration, as shown in Figure 4. Compared to the core ions, this property could be due to the slightly greater ionic radius of the dopant.

X-ray photoelectron spectroscopy (XPS) was carried out to confirm the composition and valence states of the synthesized nanostructures, as shown in Figure 5. The survey of prepared Zn-doped CuO-NSs in Figure 5a shows Auger peaks for Zn 2p, Cu 2p, C 1s, and $\mathrm{O} 1 \mathrm{~s}$. The presence of the $\mathrm{C} 1 \mathrm{~s}$ peak in the survey spectrum was due to surface contamination. The peaks that appeared in Figure $5 \mathrm{~b}$ were assigned to $\mathrm{Zn} 2 \mathrm{p}_{3 / 2}$ and $\mathrm{Zn}$ $2 \mathrm{p}_{1 / 2}$, which were positioned at $1024.3 \mathrm{eV}$ and $1047.7 \mathrm{eV}$. This indicates that $\mathrm{Zn}$ oxidized $\left(\mathrm{Zn}^{2+}\right)$ in the $\mathrm{CuO}$ nanostructures and was substituted at the $\mathrm{Cu}^{2+}$ site into the $\mathrm{CuO}$ lattice. The binding energy of major peaks, such as $\mathrm{Cu} 2 \mathrm{p}_{3 / 2}$ and $\mathrm{Cu} 2 \mathrm{p}_{1 / 2}$, appeared at $937.5 \mathrm{eV}$ and $958.4 \mathrm{eV}$, with a spin-orbit splitting of about $20.1 \mathrm{eV}$, as shown in Figure $5 \mathrm{c}$. Moreover, the presence of two satellite peaks indicated the existence of $\mathrm{Cu}^{2+}$ located at about $10 \mathrm{eV}$ higher than those of the $\mathrm{Cu} 2 \mathrm{p}_{3 / 2}$ and $\mathrm{Cu} 2 \mathrm{p}_{1 / 2}$ [42,43]. The magnified $\mathrm{O} 1 \mathrm{~s}$ peak is shown in Figure $5 \mathrm{~d}$. The broad peak was assigned to $\mathrm{O}^{2-}$ ions at a binding energy of $533.2 \mathrm{eV}$ in the $\mathrm{Cu}-\mathrm{O}$ bonding of the monoclinic structure in oxygen-deficient regions [44]. XPS results confirm the structure consisting of a $\mathrm{CuO}-\mathrm{NS}$ doped with $\mathrm{Zn}$ was in good agreement with the literature data $[45,46]$. 

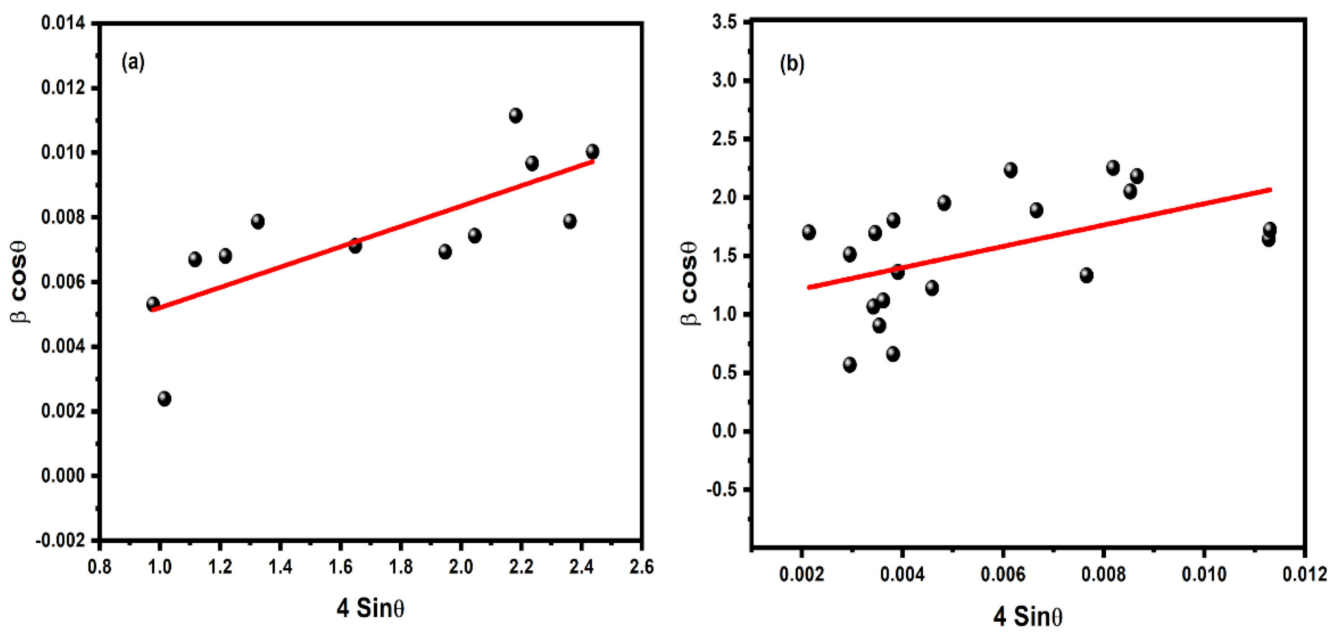

Figure 3. Williamson-Hall (W-H) analysis for (a) $\mathrm{CuO}$ and (b) $\mathrm{Zn}$-doped $\mathrm{CuO}$ nanostructures.

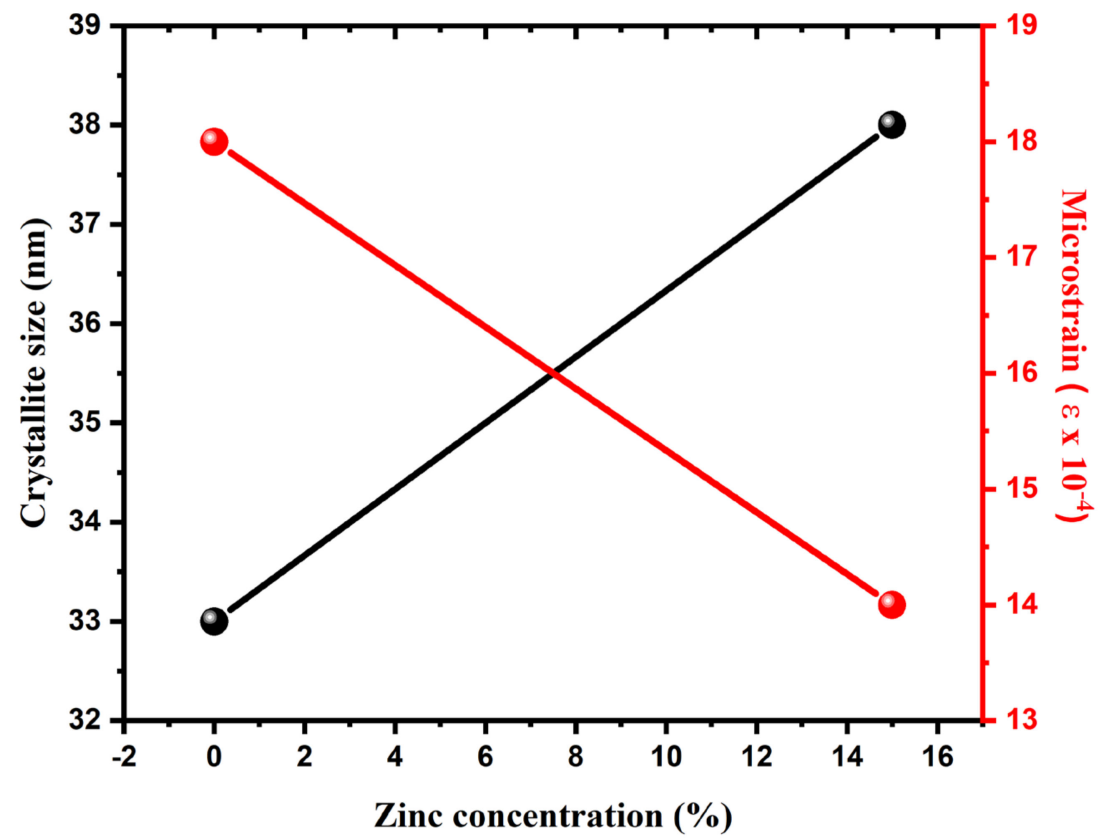

Figure 4. Analysis of microstructural parameters, such as crystallite size D and micro-strain $(\varepsilon)$, with respect to Zinc concentration for the synthesized samples.

The absorption spectrum of the $\mathrm{CuO}$ and $\mathrm{Zn}$-doped $\mathrm{CuO}-\mathrm{NS}$ is shown in Figure 6. The absorption properties for the band gap of nanostructures were recorded in the 230-800 nm range. The absorption peak for the CuO-NS was observed at $390 \mathrm{~nm}$, which moves toward the visible region with $\mathrm{Zn}$ doping. The visible light absorption capability was enhanced with $\mathrm{Zn}$ doping, which can be a potential for photocatalysis. The d-d transition among closely spaced $\mathrm{Cu}^{2+}$ and $\mathrm{Zn}^{2+}$ ions was responsible for the enhancement in the absorption of light in the visible region with Zn doping [47]. The optical band gap (Eg) of the Zn doped $\mathrm{CuO}-\mathrm{NS}$ was measured using the Tauc relation [48]. The band gap of obtained samples was measured by plotting $(\alpha \mathrm{h} v)^{2}$ versus the energy of incident photons (i.e., $\left.\mathrm{E}=\mathrm{h} v\right)$, as shown in Figure 7. There was an Eg of $2.39 \mathrm{eV}$ in the $\mathrm{CuO}-\mathrm{NS}$, which indicates important quantum confinement effects in comparison with bulk $\mathrm{CuO}(1.55 \mathrm{eV}) \mathrm{Eg}$ [49]. This reduction in Eg can be correlated with the effect of quantum confinement [49]. The same Eg value was recorded earlier for the CuO-NS [50]. Zn doping into a CuO-NS resulted in a decrease of Eg to $1.82 \mathrm{eV}$ for the $\mathrm{Zn}$-doped CuO-NS [51]. The reduction of Eg can also be considered as a result of the transition from oxygen $2 \mathrm{p}$ state to $\mathrm{d}$ state of $\mathrm{Cu}$ and $\mathrm{Zn}$. Finally, we came 
to the conclusion that high concentration $\mathrm{CuO}-\mathrm{NSs}$ doped with $\mathrm{Zn}$ had a good optical property comparable to pure $\mathrm{CuO}-\mathrm{NSs}$ [47].
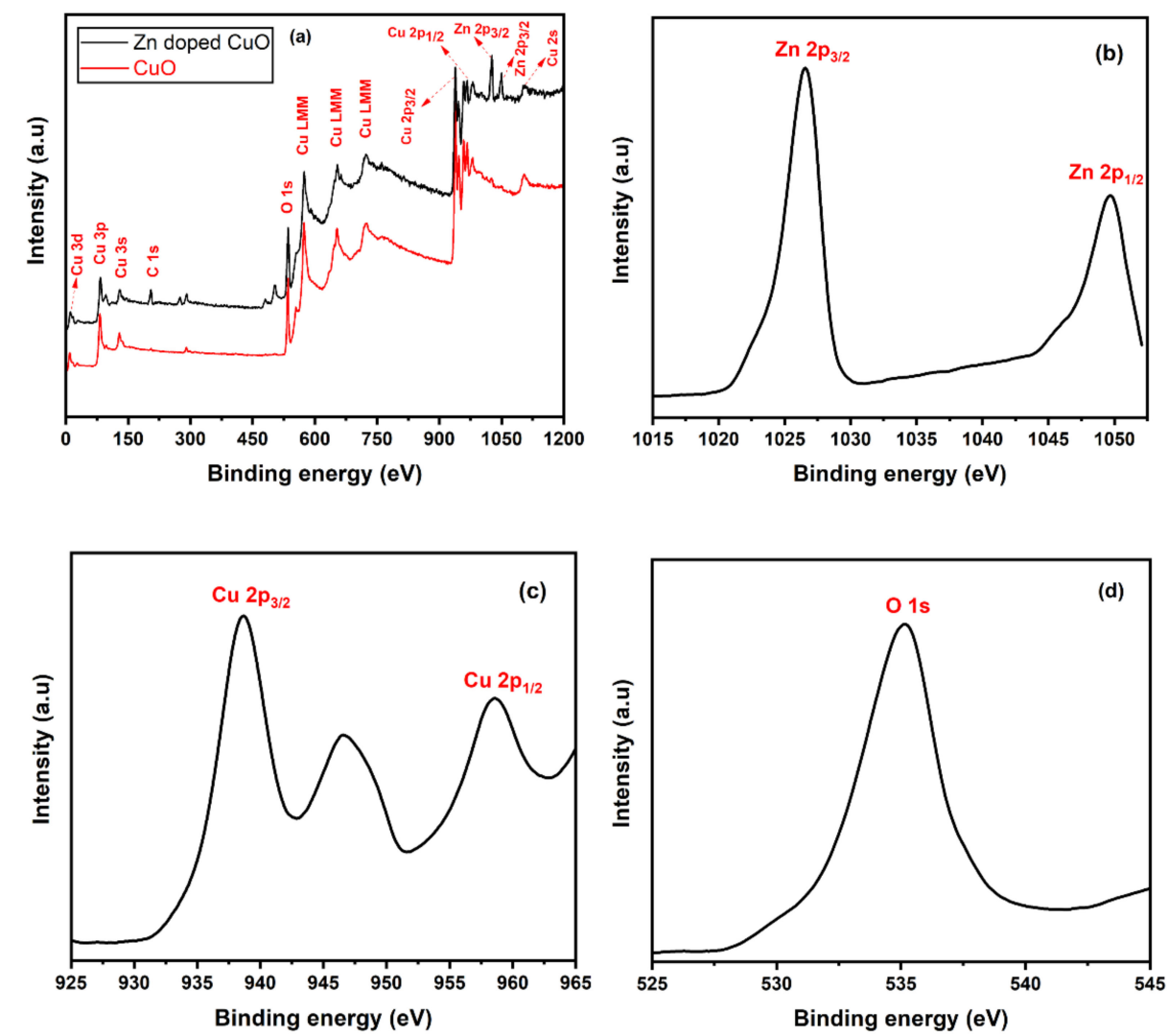

Figure 5. (a) X-ray photoelectron spectroscopy (XPS) survey of the as-synthesized Zn-doped CuO nanostructures. (b) High resolution $\mathrm{Zn} 2 \mathrm{p}$, (c) Cu 2p, and (d) O 1s XPS spectra.

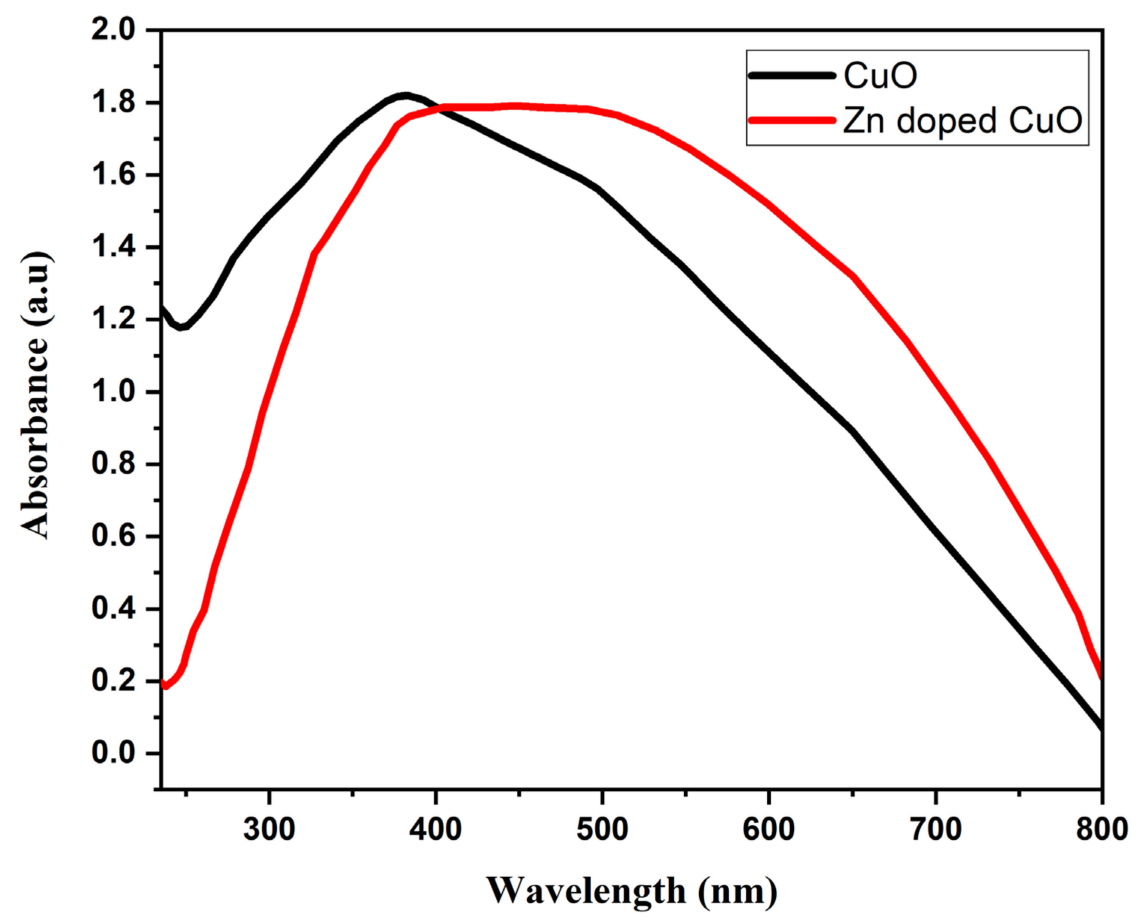

Figure 6. UV-visible absorption spectra of pure and Zinc (Zn)-doped copper oxide nanostructures (Zn-doped CuO-NSs). 


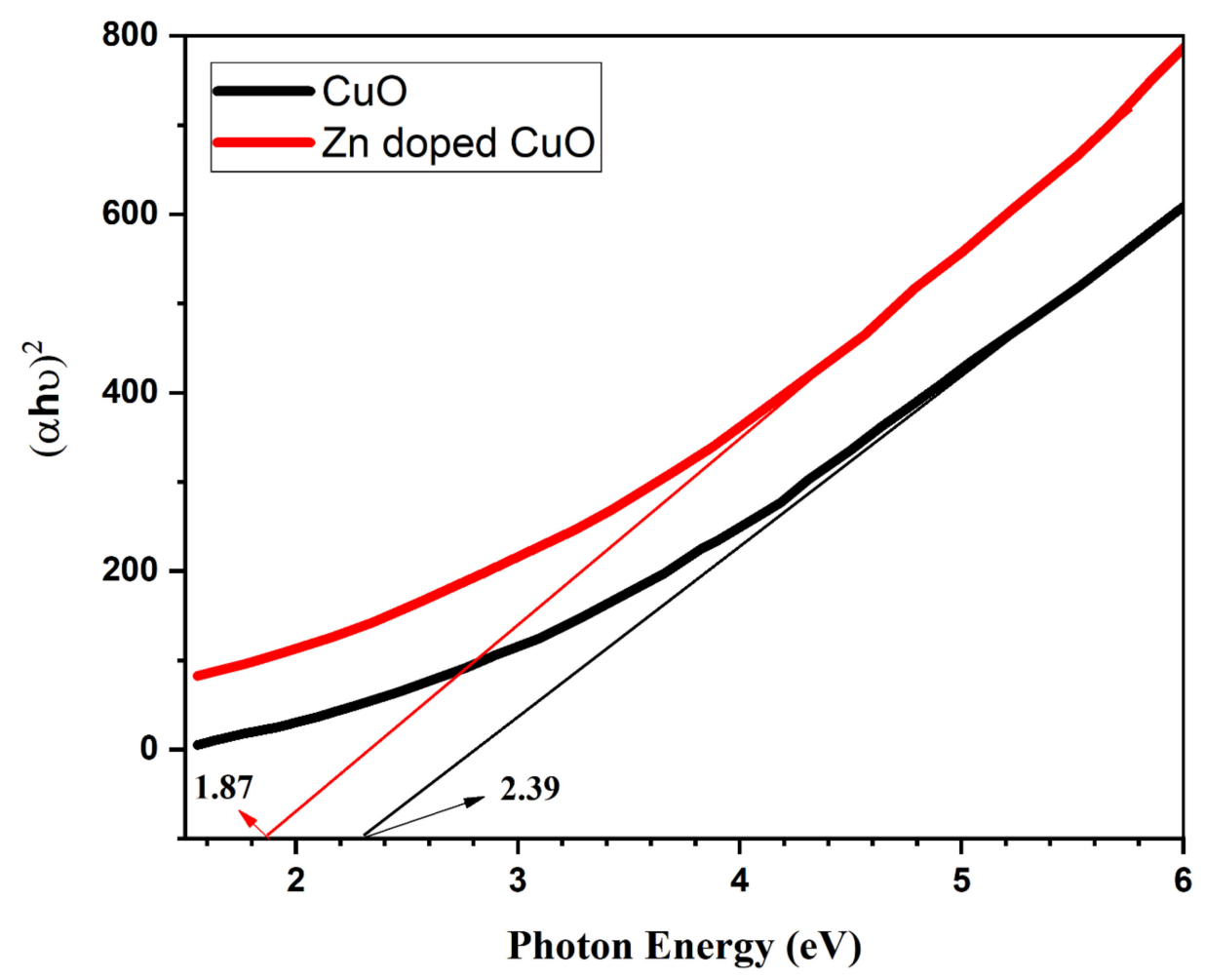

Figure 7. Band gap absorption edges of $\mathrm{CuO}$ and $\mathrm{Zn}$-doped $\mathrm{CuO}$ nanostructures.

The antibacterial potential of synthesized $\mathrm{CuO}-\mathrm{NS}$ s doped with $\mathrm{Zn}$ was observed by the agar well diffusion method [52] against American type culture collection (ATCC) bacterial strains collected from the Department of Microbiology, Hazara University Mansehra. A total of 4 bacterial strains (Pseudomonas aeruginosa $\left(\right.$ ATCC $^{\circledR}$ 10145), Klebsiella pneumonia (ATCC ${ }^{\circledR}$ $B A A-1144)$, and Escherichia coli $\left(\right.$ ATCC $\left.{ }^{\circledR} 33876\right)$ as gram-negative bacteria and Staphylococcus aureus $\left(A T C C^{\circledR} 11632\right)$ as gram-positive bacteria) were used for this study. Through various biochemical tests, all bacterial strains were identified, according to the method described [53]. A pure culture of bacteria was stored in agar slants at $4{ }^{\circ} \mathrm{C}$ for later use.

The cultures were treated with various doses of pure and Zn-doped CuO-NSs (3, $5,10 \mathrm{mg} / \mathrm{mL}$ ) dissolved in 20\% DMSO. The results demonstrate that $\mathrm{Zn}$-doped CuONSs inhibited the growth of all the tested microbes in all the tested doses, as shown in Figures 8 and 9. The zone of inhibition (ZOI) increases with an increase in the concentration of $\mathrm{Cu}$-doped $\mathrm{ZnO}-\mathrm{NS}$. We observed that gram-positive microbes were more susceptible to pure and $\mathrm{Zn}$-doped CuO-NSs as compared to gram-negative microbes. Among gramnegative microbes, $P$. aeruginosa formed a ZOI of $16 \pm 0.21 \mathrm{~mm}$ and $17 \pm 0.14 \mathrm{~m}$ and, E. coli formed $15 \pm 0.20 \mathrm{~mm}$ and $22 \pm 0.21 \mathrm{~mm} \mathrm{ZOI}$ for $\mathrm{CuO}$ and $\mathrm{Zn}$-doped $\mathrm{CuO}$, respectively. $K$. pneumonia was more sensitive to $\mathrm{Zn}$-doped $\mathrm{CuO}-\mathrm{NS}$ treatment and displayed $20 \pm 0.20 \mathrm{~mm}$ and $22 \pm 0.20 \mathrm{~mm}$ ZOI. Gram-positive microbes, such as S. aureus, formed a ZOI of $17 \pm 0.13 \mathrm{~mm}$ and $22 \pm 0.13 \mathrm{~mm}$ on the same dose for pure and $\mathrm{Zn}$-doped CuO-NSs, as shown in Table 1. All the results were carried out in triplicate, and the mean diameter of the inhibition zone was recorded and evaluated by using SPSS version 25 as shown in Figure $10 \mathrm{a}, \mathrm{b}$. Inhibition zone vs concentration bar graphs shows the diameter of the inhibition zone produced by $\mathrm{CuO}$ and $\mathrm{Zn}$-doped $\mathrm{CuO}-\mathrm{NSs}$ against gram-positive and gram-negative bacterial strains. The enhanced antibacterial activity as a result of $\mathrm{Zn}$ doping in CuO-NSs is clearly observed against all microbial strains. 


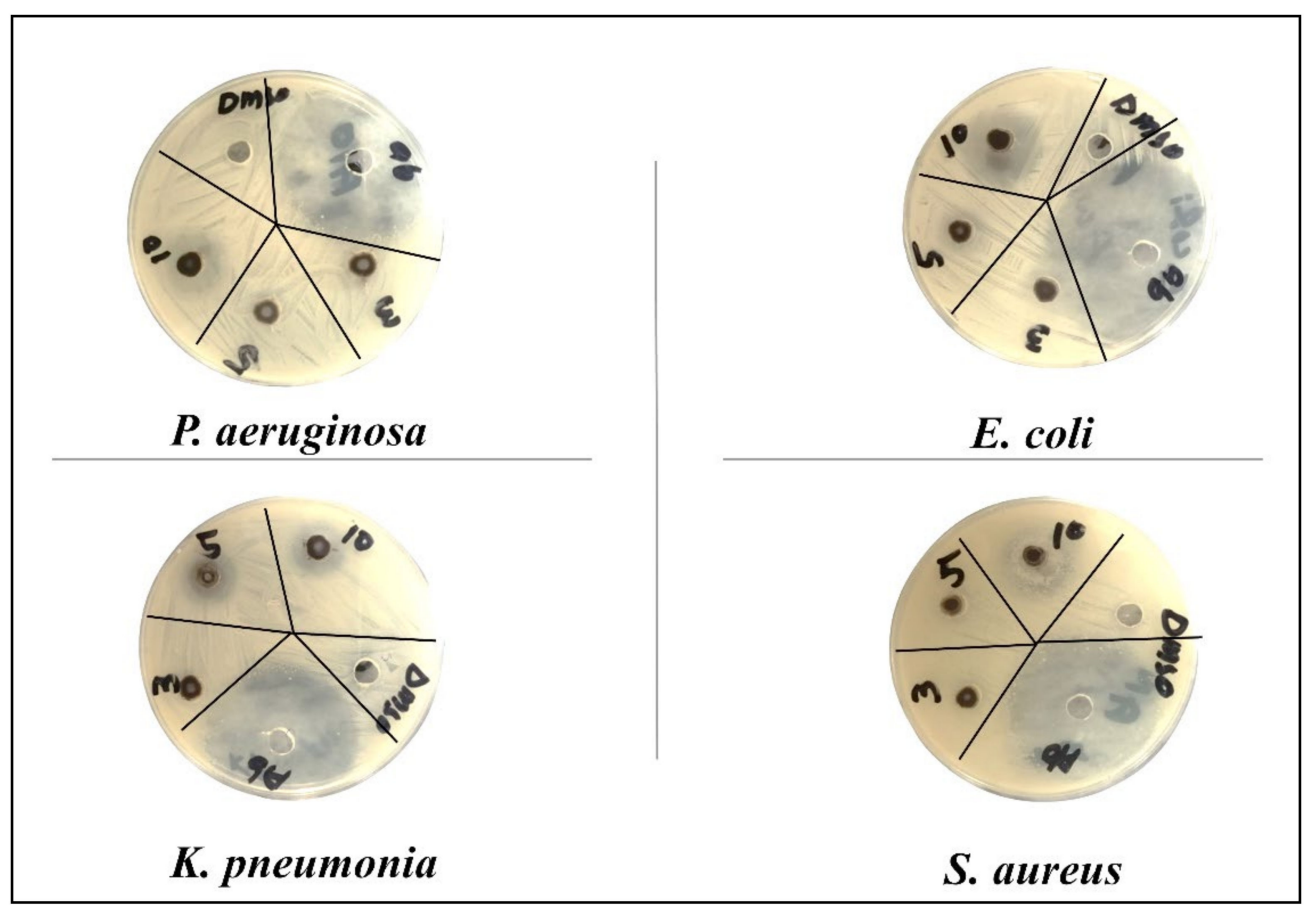

Figure 8. Zone of inhibition formed by CuO-NSs against different bacteria.

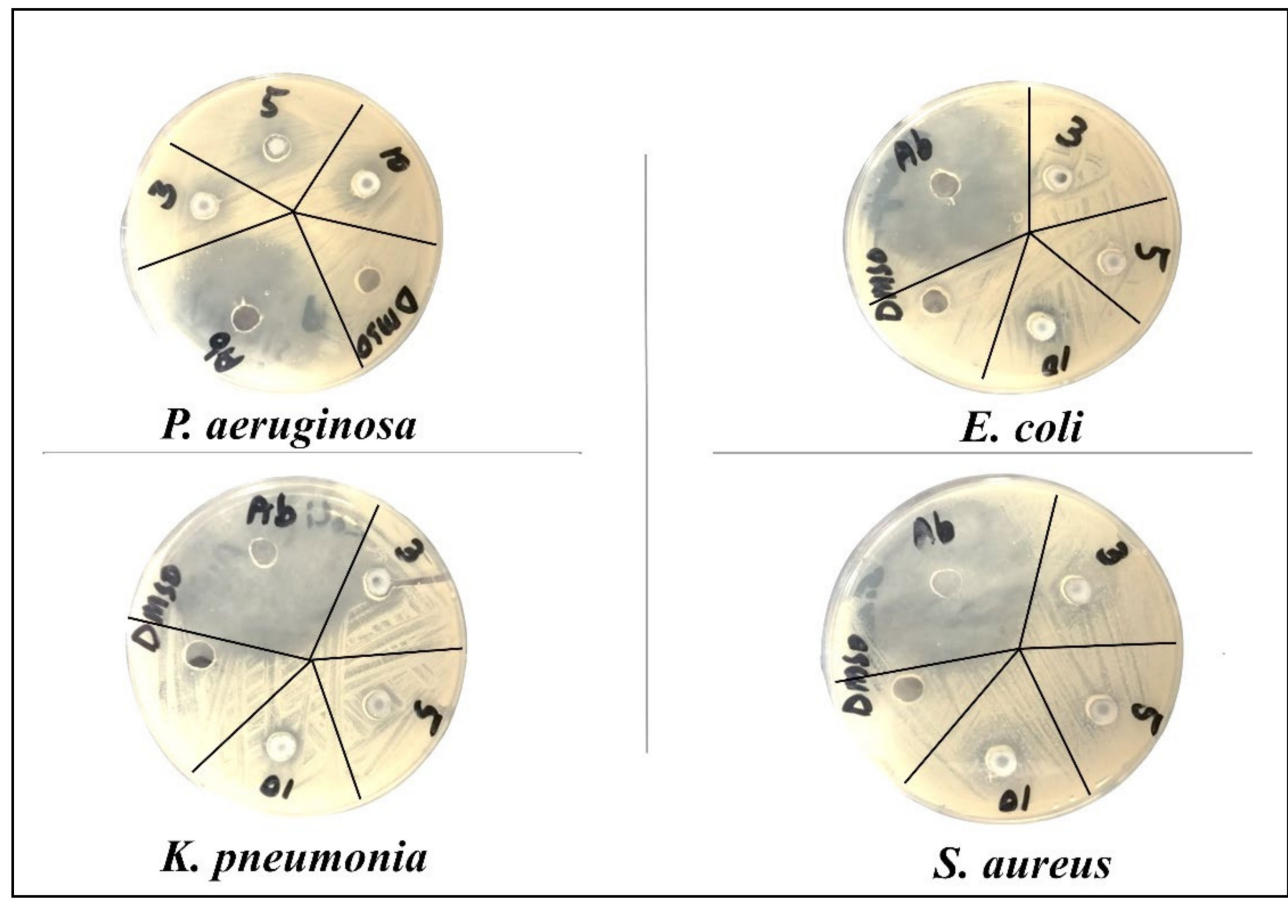

Figure 9. Zone of inhibition formed by $\mathrm{Zn}$-doped $\mathrm{CuO}-\mathrm{NSs}$ against different bacteria. 
Table 1. The table summarizes the detail of bacteria and other experimental parameters.

\begin{tabular}{|c|c|c|c|c|c|c|c|c|}
\hline & \multirow[b]{2}{*}{ Bacteria } & & \multicolumn{3}{|c|}{$\mathrm{CuO}$} & \multicolumn{3}{|c|}{ Zn Doped CuO } \\
\hline & & & $\begin{array}{c}3 \\
\mathrm{mg} / \mathrm{mL}\end{array}$ & $\begin{array}{c}5 \\
\mathrm{mg} / \mathrm{mL}\end{array}$ & $\begin{array}{c}10 \\
\mathrm{mg} / \mathrm{mL}\end{array}$ & $\begin{array}{c}3 \\
\mathrm{mg} / \mathrm{mL}\end{array}$ & $\begin{array}{c}5 \\
\mathrm{mg} / \mathrm{mL}\end{array}$ & $\begin{array}{c}10 \\
\mathrm{mg} / \mathrm{mL}\end{array}$ \\
\hline \multirow{3}{*}{$\begin{array}{c}\text { Gram } \\
\text { negative }\end{array}$} & P. aeruginosa & छ & $10 \pm 0.12$ & $12 \pm 0.20$ & $16 \pm 0.21$ & $7 \pm 0.15$ & $11 \pm 0.13$ & $17 \pm 0.14$ \\
\hline & E. coli & 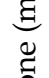 & $12 \pm 0.11$ & $14 \pm 0.11$ & $15 \pm 0.20$ & $15 \pm 0.21$ & $17 \pm 0.11$ & $22 \pm 0.21$ \\
\hline & K. pneumoniae & 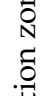 & $15 \pm 0.20$ & $20 \pm 0.15$ & $20 \pm 0.20$ & $15 \pm 0.12$ & $17 \pm 0.20$ & $22 \pm 0.20$ \\
\hline $\begin{array}{c}\text { Gram } \\
\text { positive }\end{array}$ & S. aureus & $\begin{array}{l}\text { 营 } \\
\text { 节 }\end{array}$ & $9 \pm 0.13$ & $15 \pm 0.11$ & $17 \pm 0.13$ & $12 \pm 0.14$ & $14 \pm 0.18$ & $22 \pm 0.13$ \\
\hline
\end{tabular}
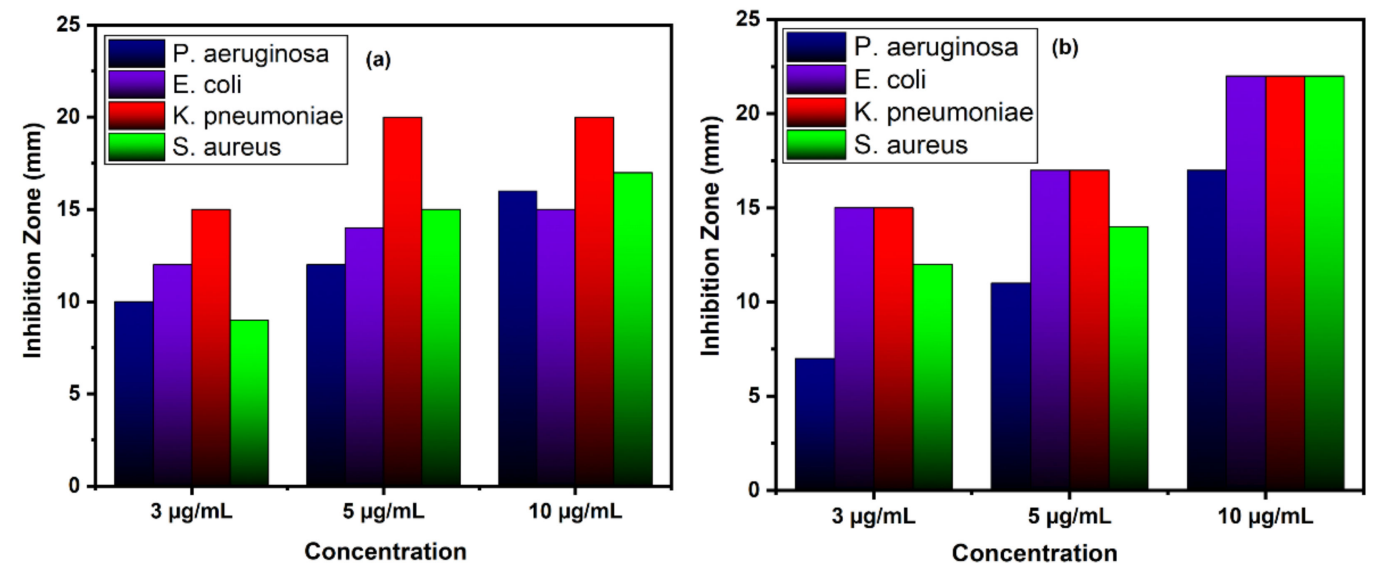

Figure 10. Bar graph showing the diameter of the zone of inhibition (in mm) produced by (a) pure and (b) Zn-doped CuO nanoparticles (NPs) against gram-positive and gram-negative bac-tria.

\section{Conclusions}

Pine-needle- and sea urchin-like pure and $\mathrm{Zn}$-doped $\mathrm{CuO}-\mathrm{NSS}$ were prepared by a simple hydrothermal route. A comparative study of the nanostructures of pure and $\mathrm{Zn}$ doped $\mathrm{CuO}$ was carried out to observe the stimulating effect of $\mathrm{Zn}$ doping on optical and antibacterial characteristics. According to x-ray diffraction analysis, Zn-doped CuO-NSs had some additional peaks compared to $\mathrm{CuO}$, which indicates that the $\mathrm{Zn}^{2+}$ effectively replaced $\mathrm{Cu}^{2+}$ in $\mathrm{CuO}$ crystal lattice. $\mathrm{CuO}$ and $\mathrm{Zn}$-doped $\mathrm{CuO}-\mathrm{NSs}$ were found to inhibit the growth of all tested bacteria. The inhibitory effect is enhanced in a dose-dependent manner. It has been observed that gram-positive microbes are more susceptible to $\mathrm{Zn}$ doped $\mathrm{CuO}-\mathrm{NSs}$ than gram-negative microbes. It is observed that $\mathrm{Zn}$ dopant brings great improvement in the antibacterial activity of CuO-NSs. This study indicates that doping is a successful strategy for the growth of the most efficient antimicrobial material.

Author Contributions: Conceptualization, A.K., P.A., S.M., I.U.D., M.A.A., and K.A.; data curation, A.K., P.A., M.U.K., and M.R.; formal analysis, A.K., P.A., A.I.A., S.M., M.R., M.R.I.F., and I.U.D.; funding acquisition, M.U.K. and K.A.; investigation, A.K., P.A., A.I.A., S.M., M.R.I.F., M.A.A., K.A., and D.A.B.; methodology, A.K., P.A., M.U.K., and M.R.; project administration, M.U.K. and K.A.; resources, P.A., A.I.A., M.U.K., M.R., M.R.I.F., I.U.D., and M.A.A.; software, M.R.I.F., I.U.D., and M.A.A.; supervision, P.A. and S.M.; validation, K.A., D.A.B., A.I.A., S.M., and I.U.D.; writingoriginal draft, A.K. and P.A.; writing-review and editing, A.K., P.A., A.I.A., S.M., M.U.K., M.R., M.R.I.F., I.U.D., M.A.A., K.A., and D.A.B. All authors have read and agreed to the published version of the manuscript.

Funding: The authors extend their appreciation to the Deanship of Scientific Research at King Saud University for funding this work through research group No. RGP-VPP-246. 
Data Availability Statement: All the data is available within the manuscript.

Conflicts of Interest: The authors declare no conflict of interest.

\section{References}

1. Rejith, S.; Krishnan, C. Optical characterizations of Zn-doped CuO nanoparticles. Sci. Acta Xaver 2013, 4, 91.

2. Magdalane, C.M.; Kaviyarasu, K.; Vijaya, J.J.; Siddhardha, B.; Jeyaraj, B. Photocatalytic activity of binary metal oxide nanocomposites of $\mathrm{CeO}_{2} / \mathrm{CdO}$ nanospheres: Investigation of optical and antimicrobial activity. J. Photochem. Photobiol. B Biol. 2016, 163, 77-86. [CrossRef] [PubMed]

3. Saleem, S.; Ahmed, B.; Khan, M.S.; Al-Shaeri, M.; Musarrat, J. Inhibition of growth and biofilm formation of clinical bacterial isolates by $\mathrm{NiO}$ nanoparticles synthesized from Eucalyptus globulus plants. Microb. Pathog. 2017, 111, 375-387. [CrossRef] [PubMed]

4. Yin, W.; Wu, L.; Ding, F.; Li, Q.; Wang, P.; Li, J.; Lu, Z.; Han, H. Surface-imprinted $\mathrm{SiO}_{2} @$ Ag nanoparticles for the selective detection of BPA using surface enhanced Raman scattering. Sens. Actuators B Chem. 2018, 258, 566-573. [CrossRef]

5. Bayansal, F.; Gülen, Y.; Şahin, B.; Kahraman, S.; Çetinkara, H. CuO nanostructures grown by the SILAR method: Influence of $\mathrm{Pb}$-doping on the morphological, structural and optical properties. J. Alloys Compd. 2015, 619, 378-382. [CrossRef]

6. Armelao, L.; Barreca, D.; Bertapelle, M.; Bottaro, G.; Sada, C.; Tondello, E. A sol-gel approach to nanophasic copper oxide thin films. Thin Solid Films 2003, 442, 48-52. [CrossRef]

7. Balamurugan, B.; Mehta, B.; Shivaprasad, S. Surface-modified CuO layer in size-stabilized single-phase $\mathrm{Cu}_{2} \mathrm{O}$ nanoparticles. Appl. Phys. Lett. 2001, 79, 3176-3178. [CrossRef]

8. Bahoosh, S.; Apostolov, A.; Apostolova, I.; Wesselinowa, J. Theory of phonon properties in doped and undoped CuO nanoparticles. Phys. Lett. A 2012, 376, 2252-2255. [CrossRef]

9. Joseph, D.P.; Venkateswaran, C.; Sambasivam, S.; Choi, B.C. Effect of Fe alloying on the structural, optical, electrical and magnetic properties of spray-deposited CuO thin films. J. Korean Phys. Soc. 2012, 61, 449-454. [CrossRef]

10. Jiang, X.; Herricks, T.; Xia, Y. CuO nanowires can be synthesized by heating copper substrates in air. Nano Lett. 2002, 2, 1333-1338. [CrossRef]

11. Jan, T.; Iqbal, J.; Ismail, M.; Badshah, N.; Mansoor, Q.; Arshad, A.; Ahkam, Q.M. Synthesis, physical properties and antibacterial activity of metal oxides nanostructures. Mater. Sci. Semicond. Process. 2014, 21, 154-160. [CrossRef]

12. Li, B.-X.; Wang, Y.-Y.; Wang, Y.-F. Facile synthesis and photocatalytic property of CuO nanostructure arrays. Acta Phys. Chim. Sin. 2009, 25, 2366-2372.

13. Liu, J.; Jin, J.; Deng, Z.; Huang, S.-Z.; Hu, Z.-Y.; Wang, L.; Wang, C.; Chen, L.-H.; Li, Y.; Van Tendeloo, G. Tailoring CuO nanostructures for enhanced photocatalytic property. J. Colloid Interface Sci. 2012, 384, 1-9. [CrossRef] [PubMed]

14. Azam, A.; Ahmed, A.S.; Oves, M.; Khan, M.S.; Habib, S.S.; Memic, A. Antimicrobial activity of metal oxide nanoparticles against Gram-positive and Gram-negative bacteria: A comparative study. Int. J. Nanomed. 2012, 7, 6003. [CrossRef] [PubMed]

15. Hassan, I.A.; Parkin, I.P.; Nair, S.P.; Carmalt, C.J. Antimicrobial activity of copper and copper (I) oxide thin films deposited via aerosol-assisted CVD. J. Mater. Chem. B 2014, 2, 2855-2860. [CrossRef]

16. Santo, C.E.; Morais, P.V.; Grass, G. Isolation and characterization of bacteria resistant to metallic copper surfaces. Appl. Environ. Microbiol. 2010, 76, 1341-1348. [CrossRef] [PubMed]

17. Hans, M.; Erbe, A.; Mathews, S.; Chen, Y.; Solioz, M.; Mücklich, F. Role of copper oxides in contact killing of bacteria. Langmuir 2013, 29, 16160-16166. [CrossRef]

18. Zhang, L.; Jiang, Y.; Ding, Y.; Povey, M.; York, D. Investigation into the antibacterial behaviour of suspensions of ZnO nanoparticles (ZnO nanofluids). J. Nanopart. Res. 2007, 9, 479-489. [CrossRef]

19. Applerot, G.; Lipovsky, A.; Dror, R.; Perkas, N.; Nitzan, Y.; Lubart, R.; Gedanken, A. Enhanced antibacterial activity of nanocrystalline $\mathrm{ZnO}$ due to increased ROS-mediated cell injury. Adv. Funct. Mater. 2009, 19, 842-852. [CrossRef]

20. Zhao, X.; Ren, X.; Zhu, R.; Luo, Z.; Ren, B. Zinc oxide nanoparticles induce oxidative DNA damage and ROS-triggered mitochondria-mediated apoptosis in zebrafish embryos. Aquat. Toxicol. 2016, 180, 56-70. [CrossRef]

21. Jones, N.; Ray, B.; Ranjit, K.T.; Manna, A.C. Antibacterial activity of ZnO nanoparticle suspensions on a broad spectrum of microorganisms. FEMS Microbiol. Lett. 2008, 279, 71-76. [CrossRef] [PubMed]

22. Schiek, M.; Al-Shamery, K.; Kunat, M.; Traeger, F.; Wöll, C. Water adsorption on the hydroxylated H- $(1 \times 1) \mathrm{O}-\mathrm{ZnO}(0001$ [combining macron]) surface. PCCP 2006, 8, 1505-1512. [CrossRef] [PubMed]

23. Jan, T.; Iqbal, J.; Mansoor, Q.; Ismail, M.; Naqvi, M.S.H.; Gul, A.; Naqvi, S.F.-u.-H.; Abbas, F. Synthesis, physical properties and antibacterial activity of Ce doped CuO: A novel nanomaterial. J. Phys. D Appl. Phys. 2014, 47, 355301. [CrossRef]

24. Malka, E.; Perelshtein, I.; Lipovsky, A.; Shalom, Y.; Naparstek, L.; Perkas, N.; Patick, T.; Lubart, R.; Nitzan, Y.; Banin, E. Eradication of multi-drug resistant bacteria by a novel Zn-doped CuO nanocomposite. Small 2013, 9, 4069-4076. [CrossRef] [PubMed]

25. Eshed, M.; Lellouche, J.; Gedanken, A.; Banin, E. A Zn-doped CuO nanocomposite shows enhanced antibiofilm and antibacterial activities against streptococcus mutans compared to nanosized CuO. Adv. Funct. Mater. 2014, 24, 1382-1390. [CrossRef]

26. Fterich, M.; Nasr, F.B.; Lefi, R.; Toumi, M.; Guermazi, S. Effect of concentration of hexamethylenetetramine in structure, microstructure and optical properties of $\mathrm{CuO}$ nanoparticles synthesized by hydrothermal route. Mater. Sci. Semicond. Process. 2016, 43, 114-122. [CrossRef] 
27. Singh, J.; Sharma, S.; Soni, S.; Sharma, S.; Singh, R.C. Influence of different milling media on structural, morphological and optical properties of the $\mathrm{ZnO}$ nanoparticles synthesized by ball milling process. Mater. Sci. Semicond. Process. 2019, 98, 29-38. [CrossRef]

28. Vieillard, J.; Bouazizi, N.; Morshed, M.N.; Clamens, T.; Desriac, F.; Bargougui, R.; Thebault, P.; Lesouhaitier, O.; Le Derf, F.; Azzouz, A. CuO nanosheets modified with amine and thiol grafting for high catalytic and antibacterial activities. Ind. Eng. Chem. Res. 2019, 58, 10179-10189. [CrossRef]

29. Bouazizi, N.; Vieillard, J.; Thebault, P.; Desriac, F.; Clamens, T.; Bargougui, R.; Couvrat, N.; Thoumire, O.; Brun, N.; Ladam, G. Silver nanoparticle embedded copper oxide as an efficient core-shell for the catalytic reduction of 4-nitrophenol and antibacterial activity improvement. Dalton Trans. 2018, 47, 9143-9155. [CrossRef] [PubMed]

30. Khan, M.M.; Harunsani, M.H.; Tan, A.L.; Hojamberdiev, M.; Azamay, S.; Ahmad, N. Antibacterial activities of zinc oxide and Mn-doped zinc oxide synthesized using Melastoma malabathricum (L.) leaf extract. Bioprocess Biosyst. Eng. 2020, 43, 1499-1508. [CrossRef]

31. Saif, S.; Tahir, A.; Asim, T.; Chen, Y.; Khan, M.; Adil, S.F. Green synthesis of ZnO hierarchical microstructures by Cordia myxa and their antibacterial activity. Saudi J. Biol. Sci. 2019, 26, 1364-1371. [CrossRef]

32. Abebe, B.; Zereffa, E.A.; Tadesse, A.; Murthy, H.A. A review on enhancing the antibacterial activity of ZnO: Mechanisms and microscopic investigation. Nanoscale Res. Lett. 2020, 15, 1-19. [CrossRef] [PubMed]

33. Prabhakaran, D.; Boothroyd, A. Single crystal growth of Zn-doped CuO by the floating-zone method. J. Cryst. Growth 2003, 250, 77-82. [CrossRef]

34. Din, S.U.; Sajid, M.; Imran, M.; Iqbal, J.; Shah, B.A.; Shah, S. One step facile synthesis, characterization and antimicrobial properties of Mg-doped CuO nanostructures. Mater. Res. Express 2019, 6, 085022. [CrossRef]

35. Barry, A.L.; Craig, W.A.; Nadler, H.; Reller, L.B.; Sanders, C.C.; Swenson, J.M. Methods for Determining Bactericidal Activity of Antimicrobial Agents: Approved Guideline; National Committee for Clinical Laboratory Standards: Wayne, PA, USA, 1999; Volume 19.

36. Ma, C.-W.; Chang, C.-M.; Huang, P.-C.; Yang, Y.-J. Sea-urchin-like ZnO nanoparticle film for dye-sensitized solar cells. J. Nanomater. 2015, 2015. [CrossRef]

37. Pung, S.; Ong, C.; Isha, K.M.; Othman, M. Synthesis and characterization of Cu-doped ZnO nanorods. Sains Malays. 2014, 43, 273-281.

38. Shirsath, S.R.; Pinjari, D.V.; Gogate, P.R.; Sonawane, S.H.; Pandit, A.B. Ultrasound assisted synthesis of doped TiO ${ }_{2}$ nano-particles: Characterization and comparison of effectiveness for photocatalytic oxidation of dyestuff effluent. Ultrason. Sonochem. 2013, 20, 277-286. [CrossRef] [PubMed]

39. Umar, A.; Harraz, F.A.; Ibrahim, A.A.; Almas, T.; Kumar, R.; Al-Assiri, M.; Baskoutas, S. Iron-doped titanium dioxide nanoparticles as potential scaffold for hydrazine chemical sensor applications. Coatings 2020, 10, 182. [CrossRef]

40. Prajapati, B.; Kumar, S.; Kumar, M.; Chatterjee, S.; Ghosh, A.K. Investigation of the physical properties of Fe: TiO 2-diluted magnetic semiconductor nanoparticles. J. Mater. Chem. C 2017, 5, 4257-4267. [CrossRef]

41. Wang, D.; Wang, Y.; Jiang, T.; Jia, H.; Yu, M. The preparation of M (M: Mn 2+, Cd 2+, Zn 2+)-doped CuO nanostructures via the hydrothermal method and their properties. J. Mater. Sci. Mater. Electron. 2016, 27, 2138-2145. [CrossRef]

42. Deng, M.-J.; Wang, C.-C.; Ho, P.-J.; Lin, C.-M.; Chen, J.-M.; Lu, K.-T. Facile electrochemical synthesis of 3D nano-architectured $\mathrm{CuO}$ electrodes for high-performance supercapacitors. J. Mater. Chem. A 2014, 2, 12857-12865. [CrossRef]

43. Dubal, D.P.; Gund, G.S.; Holze, R.; Lokhande, C.D. Mild chemical strategy to grow micro-roses and micro-woolen like arranged $\mathrm{CuO}$ nanosheets for high performance supercapacitors. J. Power Sources 2013, 242, 687-698. [CrossRef]

44. Liu, W.; Tang, X.; Tang, Z.; Chu, F.; Zeng, T.; Tang, N. Role of oxygen defects in magnetic property of Cu doped ZnO. J. Alloy. Compd. 2014, 615, 740-744. [CrossRef]

45. Zheng, L.; Zheng, Y.; Chen, C.; Zhan, Y.; Lin, X.; Zheng, Q.; Wei, K.; Zhu, J. Network structured SnO $2 / Z^{2} O$ heterojunction nanocatalyst with high photocatalytic activity. Inorg. Chem. 2009, 48, 1819-1825. [CrossRef]

46. Navarro, R.; Del Valle, F.; Fierro, J. Photocatalytic hydrogen evolution from CdS-ZnO-CdO systems under visible light irradiation: Effect of thermal treatment and presence of Pt and Ru cocatalysts. Int. J. Hydrog. Energy 2008, 33, 4265-4273. [CrossRef]

47. Iqbal, J.; Jan, T.; Ul-Hassan, S.; Ahmed, I.; Mansoor, Q.; Umair Ali, M.; Abbas, F.; Ismail, M. Facile synthesis of Zn doped CuO hierarchical nanostructures: Structural, optical and antibacterial properties. Aip. Adv. 2015, 5, 127112. [CrossRef]

48. Perelshtein, I.; Applerot, G.; Perkas, N.; Wehrschuetz-Sigl, E.; Hasmann, A.; Gübitz, G.; Gedanken, A. CuO-cotton nanocomposite: Formation, morphology, and antibacterial activity. Surf. Coat. Technol. 2009, 204, 54-57. [CrossRef]

49. Singh, D.P.; Srivastava, O.N. Synthesis and optical properties of different CuO (ellipsoid, ribbon and sheet like) nanostructures. J. Nanosci. Nanotechnol. 2009, 9, 5345-5350. [CrossRef] [PubMed] 
50. Al-Amri, S.; Shahnawaze Ansari, M.; Rafique, S.; Aldhahri, M.; Rahimuddin, S.; Azam, A.; Memic, A. Ni doped CuO nanoparticles: Structural and optical characterizations. Curr. Nanosci. 2015, 11, 191-197. [CrossRef]

51. Yayapao, O.; Thongtem, T.; Phuruangrat, A.; Thongtem, S. Sonochemical synthesis of Dy-doped ZnO nanostructures and their photocatalytic properties. J. Alloy. Compd. 2013, 576, 72-79. [CrossRef]

52. Valgas, C.; de Souza, S.M.; Smânia, E.F.; Smânia, A., Jr. Screening methods to determine antibacterial activity of natural products. Braz. J. Microbiol. 2007, 38, 369-380. [CrossRef]

53. Cowan, S.T. Cowan and Steel's Manual for the Identification of Medical Bacteria; Cambridge University Press: Cambridge, UK, 2004. 